\title{
Dependence of particle nucleation and growth on high-molecular-weight gas-phase products during ozonolysis of $\alpha$-pinene
}

\author{
J. Zhao ${ }^{1,2}$, J. Ortega ${ }^{2}$, M. Chen ${ }^{1}$, P. H. McMurry ${ }^{1}$, and J. N. Smith ${ }^{2,3}$ \\ ${ }^{1}$ Department of Mechanical Engineering, University of Minnesota, Minneapolis, Minnesota, 55455, USA \\ ${ }^{2}$ Atmospheric Chemistry Division, National Center for Atmospheric Research, Boulder, Colorado, 80307, USA \\ ${ }^{3}$ Department of Applied Physics, University of Eastern Finland, Kuopio 70211, Finland
}

Correspondence to: J. Zhao (zhaoj@umn.edu)

Received: 8 March 2013 - Published in Atmos. Chem. Phys. Discuss.: 8 April 2013

Revised: 23 June 2013 - Accepted: 5 July 2013 - Published: 8 August 2013

\begin{abstract}
We report the first time-dependent measurements of high-molecular-weight (up to $700 \mathrm{amu}$ ) gas-phase oxidation products from $\alpha$-pinene ozonolysis in an aerosol chamber under dry and low- $\mathrm{NO}_{\mathrm{x}}$ conditions. Measurements of products having mole fractions ranging from $10^{-14}$ to $10^{-11}$ were carried out with a chemical ionization mass spectrometer (the Cluster CIMS). Most products that were correlated with number concentrations of the smallest particles measured (10-20 nm) had molecular weights in the 430-560 amu range. Those products are proposed to be likely responsible for the initial nuclei formation and the early growth of the freshly nucleated particles based on their high molecular weights and chemical identities, both of which suggest low-volatility compounds. Another group of oxidation products in the lower mass range of 140-380 amu was well correlated with particles larger than $20 \mathrm{~nm}$. We postulate that those products contributed to the later growth of particles (i.e., larger than $20 \mathrm{~nm}$ in diameter). Although particle nucleation in this study was primarily due to condensation of oxidation products from $\alpha$-pinene ozonolysis, the involvement of residual sulfuric acid vapor in particle nucleation cannot be totally excluded.
\end{abstract}

\section{Introduction}

The formation of nanoparticles by nucleation of atmospheric trace gases can be a significant source of cloud condensation nuclei $(\mathrm{CCN})$. Accurate representations of the indirect effect of aerosols on climate require better models for the chemical processes responsible for the nucleation and growth rates that control the chemical properties and concentration of CCN (Kuang et al., 2009; Merikanto et al., 2009; Yu and Luo, 2009; Kerminen et al., 2005; Laaksonen et al., 2005). Also, the assessment of potential human health risks linked to episodes of particulate matter pollution depends on the sizeresolved aerosol chemical composition (Breitner et al., 2011; Franck et al., 2011). There is hence a need to understand the physical and chemical processes responsible for nanoparticle formation and growth in the atmosphere.

The last two decades have witnessed steady progress towards understanding the formation mechanisms of atmospheric nanoparticles in the continental boundary layer (Chen et al., 2012; Zhang et al., 2012; Kirkby et al., 2011; Bzdek and Johnston, 2010; Kulmala et al., 2004). It is commonly accepted that atmospheric nucleation is a multicomponent process that involves both inorganic and organic trace species. One unique species, gaseous sulfuric acid, is almost always found to be involved in the initial nuclei formation, and its concentrations are highly correlated with the formation rates of newly formed nanoparticles. However, typical sulfuric acid concentrations $\left(10^{6}-10^{7} \mathrm{~cm}^{-3}\right)$ are too low to account for the observed early rapid growth of atmospheric nanoparticles (Paasonen et al., 2010; Boy et al., 2008; Iida et al., 2008; Kuang et al., 2008; Riipinen et al., 2007; Sihto e tal., 2006; Stolzenburg et al., 2005; Weber et al., 1996, 1997, 2001). Therefore, there must be other species that contribute to the early growth process, and different processes 
may dominate in different atmospheric regimes. Laboratory experiments and quantum chemical studies showed that both atmospheric acidic (e.g., carboxylic acids) and basic compounds (ammonia and amines) can enhance nucleation rates at given sulfuric acid and water concentrations (Chen et al., 2012; DePalma et al., 2012; Kupiainen et al., 2012; Yu et al., 2012; Zollner et al., 2012; Erupe et al., 2011; Nadykto et al., 2011; Kirkby et al., 2011; Berndt et al., 2010; Metzger et al., 2010; Wang et al., 2010a; Zhang et al., 2009, 2004; Zhao et al., 2009; Kurten et al., 2008). Furthermore, recent chamber experiments and field observations showed that, in sulfur-rich environments, nucleation can be explained by a simplified acid-base model through the formation of electrically neutral sulfuric acid and amine- and/or ammoniacontaining clusters (Chen et al., 2012; Jiang et al., 2011). One recent study found that evaporation of sulfuric acid from dimers and trimers (clusters that respectively contain two and three sulfuric acid molecules plus unknown numbers of water and base molecules) limits nucleation, and that the nucleation rate (i.e., the rate at which stable clusters are produced) equals the tetramer formation rate (Chen et al., 2012).

While significant progress has been made towards understanding the formation mechanisms of atmospheric nanoparticles from sulfuric acid, much less is known about nanoparticles formed from other precursor gases such as biogenic organic compounds. A well-known example is the blue haze formation over forests, which has been attributed to aerosols formed from biogenic volatile organic compounds (BVOCs) (Went, 1960). Recent laboratory experiments showed that blue haze over forests can be enhanced by the interaction between organic acids of biogenic origin and sulfuric acid (Zhang et al., 2009). However, it is unclear whether BVOCs and/or their oxidation products over forests can form nuclei without the direct involvement of sulfuric acid vapor.

While little is understood about processes responsible for nucleation and the early stages of growth from BVOCs, it is known that organic compounds are significant or even dominant constituents of ambient submicron aerosols globally (Jimenez et al., 2009; Zhang et al., 2007), and many of these compounds have biogenic origins. For example, products of terpene oxidation were observed to be significant components of ambient submicron particles at various locations (Hyder et al., 2012; Wagener et al., 2011; Yasmeen et al., 2010; Szmigielski et al., 2007; Cahill et al., 2006; Herckes et al., 2006). In forested areas where biogenic emissions dominate, with minimal influences of anthropogenic pollution, BVOCs are hypothesized to play a more dominant role than sulfuric acid vapor in the formation of initial nuclei (Paasonen et al., 2010). The monoterpenes $\alpha$ - and $\beta$-pinene are among the most abundant terpenes globally, second only to isoprene (Guenther et al., 1995). They react with atmospheric oxidants (e.g., $\mathrm{OH}$ radicals and ozone) to form a variety of oxidation products, some of which are sufficiently nonvolatile to form secondary organic aerosols. Some oxidation products such as pinic acid and cis-pinonic acid from pinene ozonolysis have been identified in ambient secondary organic aerosols collected over forests (Hyder et al., 2012; Yasmeen et al., 2010; Claeys et al., 2009; Szmigielski et al., 2007; Herckes et al., 2006).

Oxidation of $\alpha$ - and $\beta$-pinene has been studied more than that of other monoterpenes because of their ubiquity and their important roles in secondary organic aerosol formation. Most previous laboratory chamber studies focused either on the aerosol yields or on identification of individual gas-phase products and their yields (Perraud et al., 2012; Chen et al., 2009, 2011; Lee et al., 2006; Berndt et al., 2003; Yu et al., 1999). In these studies, many multifunctional oxidation products were identified in both gas and particulate phases. The chemical composition of laboratory-generated particles from ozonolysis of pinenes has been measured with off-line methods, and oligomers were found to be the major constituents of secondary organic aerosols (Hall and Johnston, 2011, 2012a, b; Heaton et al., 2007). Winkler et al. (2012) showed that the chemical composition of nanoparticles generated from ozonolysis of $\alpha$-pinene depends on particle size: 10 and $20 \mathrm{~nm}$ particles were enhanced in low-volatility carboxylic acids, while $40 \mathrm{~nm}$ particles showed higher concentrations of carbonyl-containing compounds and low-molecular-weight organic acids (Winkler et al., 2012). This finding reveals the important role of the Kelvin effect in the growth of biogenic nanoparticles. Viitanen et al. (2010) showed that gas-phase compounds with a mobility diameter of $1.4 \mathrm{~nm}$, corresponding to a molecular weight of $\sim 355 \mathrm{amu}$, were responsible for particle nucleation from $\alpha$-pinene ozonolysis in a chamber study using ion mobility spectrometry (Viitanen et al., 2011).

Recently, Ehn et al. conducted chamber experiments of $\alpha$ - and $\beta$-pinene ozonolysis. Naturally charged negative ions (ions that are produced from collisions of air molecules with energetic particles, mainly galactic cosmic rays or radon) formed during the ozonolysis were measured with a highresolution Atmospheric Pressure interface-Time Of Flight mass spectrometer (APi-TOF) (Ehn et al., 2012). Most of the ions were identified as clusters containing a negatively charged nitrate ion $\left(\mathrm{NO}_{3}^{-}\right)$, the latter of which serves as the reagent ion that makes ion detection possible for the APiTOF. Based on the ion spectra, the corresponding highly oxidized multifunctional (HOM) neutral products were identified with an $\mathrm{O} / \mathrm{C}$ ratio of $0.7-1.3$. The HOM products were proposed to be generated via formation of geminal diols and/or hydroperoxides in the gas phase rather than in the aerosol phase. However, Ehn et al. (2012) only measured the steady-state signals of the oxidation products; the timedependent intensities of individual products that are related to the initial particle formation were not reported. In addition, the concentrations of particles larger than $3 \mathrm{~nm}$ were found to be very low $\left(<10 \mathrm{~cm}^{-3}\right)$ during the experiments. Hence no correlations between the HOM products and newly formed particles were reported in their study. 
In this study, we measured gas-phase oxidation products from $\alpha$-pinene ozonolysis using the Cluster CIMS (Zhao et al., 2010). There are three major differences between measurements in this study and those reported in Ehn et al. (2012).

1. Instead of measuring naturally charged ions, the Cluster CIMS measured ions formed from chemical ionization of neutral oxidation products. The ion concentrations are thus much higher than those from naturally charged ions. Hence the Cluster CIMS has enough sensitivity to measure the oxidation products with a much shorter measurement cycle, which allows measurements of time-dependent profiles during particle nucleation.

2. The average residence time used in this study (determined by the chamber volume divided by the total flow rate) is much longer than that in Ehn et al. (2012) ( $300 \mathrm{~min}$ vs $50 \mathrm{~min})$, which allows growth of particles to larger sizes and accumulation of sufficient concentrations of particles to be measured. Timedependent concentrations of both particles and gasphase oxidation products were measured for the entire experiments (typically 20 h) in this study, while only the steady-state concentrations of gas-phase oxidation products were measured in Ehn et al. (2012).

3. Concentrations of measured oxidation products were estimated by directly applying the equation derived from chemical ionization (Zhao et al., 2010). The concentrations were determined by the relative abundances of the ions resulting from ionization of the oxidation products and the reagent ions and thus avoid the high uncertainties caused by estimating the lifetimes of the product ions (Ehn et al., 2012).

We report the first time-dependent concentrations of gasphase oxidation products during the entire process from initial nuclei formation and growth to the occurrence of a later secondary nucleation event. The oxidation products were classified based on their characteristic temporal profiles and the correlations between the product abundances and the particle concentrations. Gas-phase oxidation products that likely lead to the initial formation and growth of new particles were identified. The mechanisms of the particle nucleation and growth products are discussed.

\section{Experimental section}

\subsection{Experimental setup}

The experiments were carried out in a $10 \mathrm{~m}^{3}$ continuous flow reaction chamber shown in Fig. S1. These experiments were performed under dark conditions. Dry $(\mathrm{RH}<1 \%)$ zero air (model 737, Aadco Instruments Inc.) flowed through the chamber at $\sim 30 \mathrm{lpm}$, resulting in a mean residence time of about $5 \mathrm{~h}$. Ozone was introduced into the chamber by passing one half of the total zero air flow $(15 \mathrm{lpm})$ through a $4.5 \mathrm{~cm}$ inner-diameter stainless steel tube containing a mercury lamp, which exposed the air to UV light. Ozone concentrations were regulated by adjusting the length of the mercury lamp that was in contact with the air flow. The vapor was added to the remaining zero air flow from a gas cylinder containing $7 \mathrm{ppm} \alpha$-pinene in nitrogen. The $\alpha$-pinene cylinder was prepared by introducing the liquid (Sigma-Aldrich, purity $\geq 99.5 \%$ ) into an electro-polished aluminum cylinder and pressurizing with UHP nitrogen. The final $\alpha$-pinene concentration was verified using gas chromatography with flame ionization detection (GC-FID) and compared with a NIST-certified benzene standard. The $\alpha$-pinene flow was initiated at least $10 \mathrm{~h}$ before ozone was added in order to reach its steady-state concentration of about 5-20 ppb. No attempt to remove $\mathrm{OH}$ radicals from ozone-alkene reactions was made in these experiments. The $\mathrm{OH}$ radicals are formed through a complex process that involves collisional stabilization and subsequent thermal decomposition of Criegee intermediates, and the competition of the decomposition with other reactions between the intermediates and reactants such as sulfur dioxide, water, aldehydes, and organic acids (Kroll et al., 2001). An $\mathrm{OH}$ yield of greater than $70 \%$ has been demonstrated during the ozonolysis of $\alpha$-pinene (Forester and Wells, 2011; Siese et al., 2001; Paulson et al., 1998). So both $\mathrm{OH}$ and ozone likely contributed to the formation of the reaction products detected in this study. In addition, aging by the $\mathrm{OH}$ radicals can significantly increase the concentration of first-generation biogenic secondary organic aerosols as has recently been demonstrated by Donahue et al. (2012). Several instruments were used to monitor trace gases, gasphase precursors and products, and particles. A home-built proton transfer reaction mass spectrometer (PTR-MS) monitored the concentration of $\alpha$-pinene and a limited number of volatile gas-phase products (e.g., pinonaldehyde). Gas-phase species were also detected with the Cluster CIMS (Zhao et al., 2010). A scanning mobility particle sizer (SMPS) measured particle size distributions in the $10-350 \mathrm{~nm}$ size range with a $\sim 5$ min measurement cycle. Typical experiment times were about $20 \mathrm{~h}$ from the start of ozone addition until several hours after the occurrence of a secondary particle formation event.

As a routine cleaning procedure, after each experiment high ozone levels (several $\mathrm{ppm}$ ) were introduced into the chamber with the zero air flow to oxidize residual organic compounds. This air was used to flush the chamber and then vented into the laboratory exhaust. The background concentrations of gas-phase precursors and pre-existing particles met the following criteria prior to each experiment unless otherwise specified: $<10 \mathrm{ppt}$ for $\alpha$-pinene, $<1 \mathrm{ppb}$ for ozone, and $<2 \mathrm{~cm}^{-3}$ for particles larger than $10 \mathrm{~nm}$. Concentrations of other trace gases such as $\mathrm{NO}_{\mathrm{x}}$ and $\mathrm{SO}_{2}$ were not measured but were expected to be low $(<0.1 \mathrm{ppb})$ according to the zero-air-generator specifications. During one 


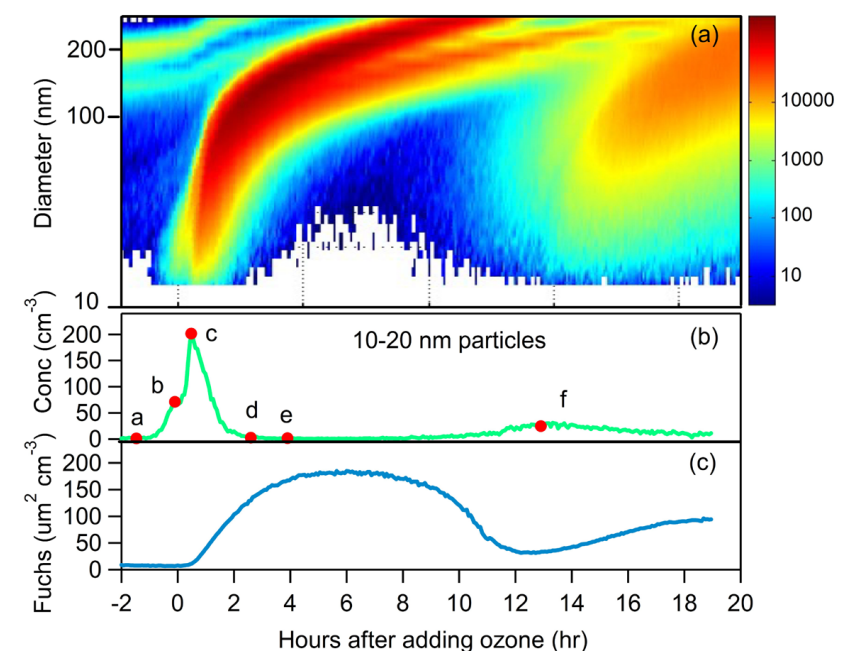

Fig. 1. Characteristics of particle formation from $\alpha$-pinene ozonolysis for E1: (a) contour plot of the particle size distribution measured with the SMPS in the $10-350 \mathrm{~nm}$ diameter range; (b) total number concentration of particles between 10 and $20 \mathrm{~nm}$. Points a-f denote the corresponding characteristic times as indicated below: $\mathrm{a}(t=-1.7 \mathrm{~h})$, background levels; $\mathrm{b}(t=0 \mathrm{~h})$, addition of ozone; c $(t=0.5 \mathrm{~h})$, reaching peak concentrations of Category I products for the first particle formation event; $\mathrm{d}(t=2.6 \mathrm{~h})$, disappearance of almost all $10-20 \mathrm{~nm}$ particles; e $(t=3.9 \mathrm{~h})$, approaching steady-state concentration of Category I products; $\mathrm{f}(t=12.9 \mathrm{~h})$, reaching peak concentrations of Category I products for the second particle formation event (see text for the definition of Category I products). (c) Estimated time-dependent Fuchs surface area (in $\mu \mathrm{m}^{2} \mathrm{~cm}^{-3}$ ).

of the experiments, E1, background level exceeded the criteria presented above. Prior to that experiment, which is described in detail below, there were detectable levels of oxidized VOCs and a moderately high $\left(\sim 50 \mathrm{~cm}^{-3}\right)$ concentration of $10-20 \mathrm{~nm}$ diameter particles. The source of those background oxidized VOCs and particles is not known. It is possible that they were formed from the residual products of the prior experiment. However, the amount of aerosol formed after the ozone was added greatly exceeded the amount of aerosol present when the ozone was added (point $b$ in Fig. 1b). Although E1 was not ideal in this regard, it is representative of all experiments performed for which the background criteria were met. Once the $\alpha$-pinene concentration reached steady state, ozone was introduced into the chamber. In most experiments, the steady-state ozone concentration was $\sim 50-100 \mathrm{ppb}$. The ozone was sampled from a port opposite the inlet using a UV photometric ozone analyzer (Model 49, Thermo Scientific Inc.).

\subsection{Cluster CIMS}

A detailed description of the Cluster CIMS along with illustrative measurements can be found in recent publications (Jiang et al., 2011; Zhao et al., 2010, 2011). Only the aspects relevant to the present study are described here. The Cluster
CIMS inlet was modified to allow interfacing to the chamber. The inlet was shortened to $50 \mathrm{~cm}$, which is half the length of the inlet used for ambient measurements. A sample flow of $10 \mathrm{lpm}$ was drawn from the chamber through a $1.25 \mathrm{~cm}$ outerdiameter Teflon tube. The $\mathrm{N}_{2}$ flow rate through the ion source was set to $1 \mathrm{lpm}$ to minimize sample flow dilution. The reaction time for the reagent ions with the sampled products was estimated to be $\sim 0.2 \mathrm{~s}$. For most experiments, we generated nitrate ions (the reagent ions) by introducing trace amount of nitric acid into the $\mathrm{N}_{2}$ flow through the ion source to measure gas-phase oxidation products, similar to the detection scheme that was employed in previous ambient measurements (Zhao et al., 2010). We also carried out exploratory experiments to measure more gas-phase oxidation products by employing acetate, a less selective reagent ion (Veres et al., 2008, 2010). The Cluster CIMS acquires the spectra in 100-700 amu range using a quadrupole mass spectrometer, with a measurement cycle of about $10 \mathrm{~min}$ in length.

\section{Results and discussion}

\subsection{Species pertinent to particle nucleation and growth}

Three experiments (E1-E3) are discussed in this paper and their experimental conditions are summarized in Table S1. Most of the data presented below are from E1; similar results from E2 and E3 can be found in the Supplement. Ozone concentrations increased linearly at a rate of $0.1-0.2 \mathrm{ppb} \mathrm{min}^{-1}$ during the first three hours, and during this period an intense new particle formation event occurred, as shown in Fig. 1a and $\mathrm{b}$ for E1. Concentrations of the smallest measured particles (10-20 nm diameter) began to increase within $1 \mathrm{~h}$ after ozone was first introduced, and reached peak values of about $200-250 \mathrm{~cm}^{-3}$ after $0.5-1.5 \mathrm{~h}$ (Fig. $1 \mathrm{~b}$, point c, for E1; see also Fig. S2b for E2 and Fig. S3b for E3). Evidence of a second particle formation event beginning at about $8-10 \mathrm{~h}$ is also evident in all three experiments (e.g., Fig. 1b, point f). This probably occurs because the surface area of particles decreased (Fuchs surface area in Figs. 1c, S2c, and S3c), allowing the concentrations of condensable species to build up until new nuclei are formed and subsequently grow to detectable sizes (Kuang et al., 2010). Because no scavenger was added to remove $\mathrm{OH}$ radicals, we cannot rule out the possibility that reactions of $\mathrm{OH}$ radicals with products from $\alpha$-pinene ozonolysis contributed to nucleation. Evidence for periodic bursts of nucleation has previously been observed in other studies (VanReken et al., 2006; McGraw and Saunders, 1984). In addition, at almost the same time, a distinct bimodal particle growth pattern is formed with a minimum number concentration observed at $150 \mathrm{~nm}$ diameter (Figs. 1a, S2a, and S3a). Similar observations have previously been reported for the ozonolysis of isoprene (Kamens et al., 1982).

Figure $2 \mathrm{a}$ shows correlations between the concentrations of $10-20 \mathrm{~nm}$ particles and the oxidation products that are 
detected by the Cluster CIMS for which observed abundances are higher than their background levels. Figure $2 b$ shows correlations for particles larger than $20 \mathrm{~nm}$. The correlations are separated into three groups, which are shown in red (Category I), blue (Category II), and gray (Category III). The Category I compounds are mostly in the range of 490-630 amu, except for several in the ranges of 300-400 and 430-480 amu, and are well correlated with the smallest particles detected $(10-20 \mathrm{~nm}$ ) (correlation coefficients $\geq 0.5$ for most of Category I compounds except for 480, 530, 558 and $560 \mathrm{amu}$ ); we infer that these compounds may be associated with particle nucleation. In the beginning of most experiments (in the absence of ozone), the chamber is typically free of particles and hence near-zero particle surface area is expected. Without an aerosol source of condensation sink (i.e., not considering wall losses that are constant during the experiment), condensable products build up rapidly upon ozone addition. Saturation ratios of those species increase quickly and, above a certain limit, homogenous nucleation and rapid growth occur. For E1, the background concentrations of $10-20 \mathrm{~nm}$ particles are associated with detectable Category I products. Also a sharp increase of $10-20 \mathrm{~nm}$ particle concentration was observed upon addition of ozone that clearly exceeded the concentration of any background particles (Fig. 1a). The Category II compounds are in the 140-380 amu range and are correlated with number concentrations of particles larger than $20 \mathrm{~nm}$ (correlation coefficients $\geq 0.5$ ); we infer that these compounds may be associated with particle growth. Category III compounds are not correlated with the concentrations of particles in either of those size ranges.

Figure $3 \mathrm{a}$ shows a time series plot of the number concentration of 10-20 nm particles and the total concentration of Category I compounds. The concentration of individual Category I compounds follows a similar trend. Estimated concentrations of the gas-phase products were obtained by applying the previously measured mass-dependent sensitivities of the Cluster CIMS and assuming an ion-molecule rate constant of $2 \times 10^{-9} \mathrm{~cm}^{3} \mathrm{~s}^{-1}$ and a reaction time of about $0.2 \mathrm{~s}$ (Zhao et al., 2010, ref. Fig. S4 for the massdependent sensitivities used to determine species concentrations). As mentioned in Sect. 2.1, during E1 some Category I products were detected $1 \mathrm{~h}$ prior to ozone addition. Nevertheless, for this and all other experiments (ref. Fig. 1a, b; Figs. S2a, b; Fig. S3a, b in the Supplement), increases in the concentrations of $10-20 \mathrm{~nm}$ particles occurred about $0.5-1 \mathrm{~h}$ after the concentrations of Category I products were observed to increase. This time delay may be associated with the time required for nuclei to grow to $10 \mathrm{~nm}$, the minimum size that was measured in this study. Once particle formation is observed, the Category I compounds and $10-20 \mathrm{~nm}$ particles follow similar temporal profiles for about $2-3 \mathrm{~h}$, reaching peak concentrations almost at the same time (Fig. 3a, point c). Subsequently, particle concentrations drop to near zero as nucleated particles grow beyond the $10-20 \mathrm{~nm}$ di-

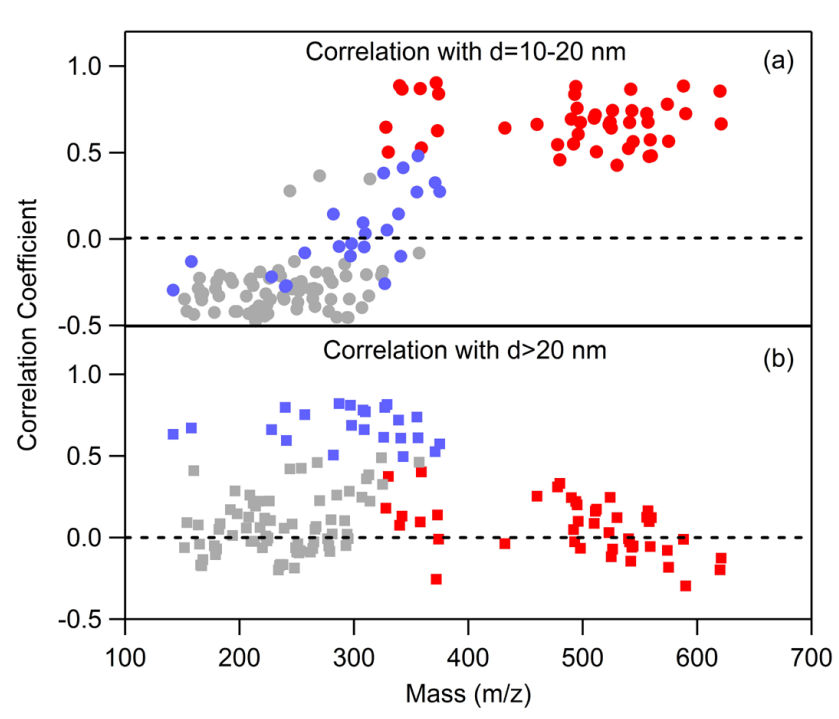

Fig. 2. Coefficients of correlation between gas-phase oxidation products and particles for E1: (a) with 10-20 nm particles; (b) with particles larger than $20 \mathrm{~nm}$. Color codes: red - Category I products; blue - Category II products; gray - Category III products (see text for the definition of the three categories). The correlations were performed between concentrations of products and the number concentrations of particles for period $t=0-10 \mathrm{~h}$ in Fig. 1b. The horizontal dash lines indicate zero correlation coefficients.

ameter interval (point d), while concentrations of Category I compounds reach approximately steady-state levels (point e). As the experiment continues past the $6 \mathrm{~h}$ mark, Category I compounds appear to be anti-correlated with the Fuchs surface area (ref. Figs. 1c and 3a), increasing above the steadystate concentration at about $8 \mathrm{~h}$, reaching a secondary maximum at $\sim 13 \mathrm{~h}$, and then decreasing during the second particle formation event. The number concentration of $10-20 \mathrm{~nm}$ particles follows a similar trend: at about $8-10 \mathrm{~h}$, their concentration again starts to increase, reaching a secondary peak of about $30-40 \mathrm{~cm}^{-3}$ at $\sim 14 \mathrm{~h}$. The formation rate for $10 \mathrm{~nm}$ particles during the second event, $J_{10 \mathrm{~nm}}$, was much lower than for the first event (about 0.038 vs. $0.42 \mathrm{~cm}^{-3} \mathrm{~s}^{-1}$; see Supplement Sect. II for a discussion of particle formation and growth rates). If Category I compounds were responsible for nucleation in both cases, their lower concentrations during the second event would have led to lower nucleation rates. As mentioned previously, the results from E2 and E3 were similar to those of E1. However, no obvious increase of concentrations of Category I compounds was found for E2 during the second particle formation event, probably due to a lower formation rate (see Supplement Sect. II) that requires a lower concentration (about $1.2 \times 10^{7} \mathrm{~cm}^{-3}$ for the steadystate concentration, Fig. S5).

Figure $3 \mathrm{~b}$ shows the time series plot of the total concentration of Category II compounds and the concentration of particles larger than $20 \mathrm{~nm}$. Again, the concentration of individual Category II compounds follows a similar trend. These 


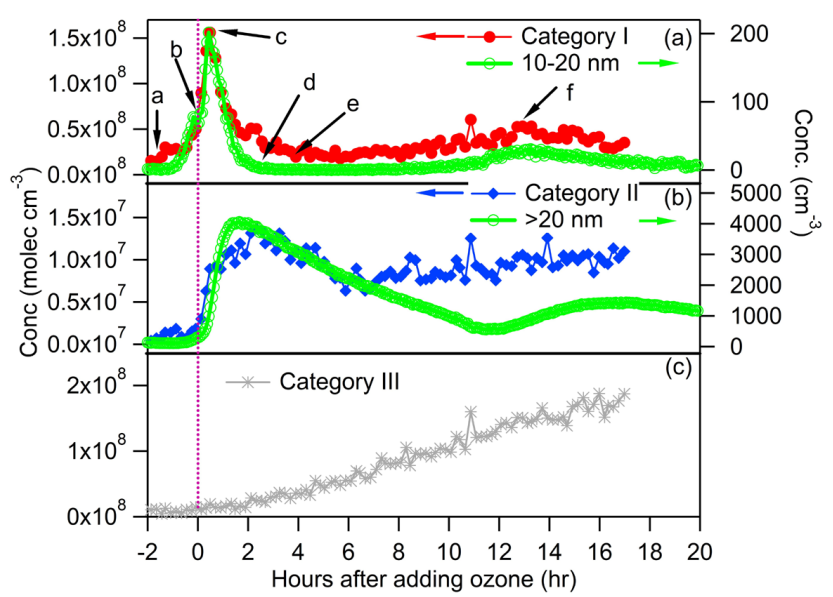

Fig. 3. Time-dependent total concentrations of the three category (I-III) products measured with the Cluster CIMS, along with the total concentrations of two category particles (10-20 nm particles and particles larger than $20 \mathrm{~nm}$ measured with the SMPS for E1). (a) Category I products and $10-20 \mathrm{~nm}$ particles, points a-f correspond to times a-f in Fig. 1b; (b) Category II products and particles larger than $20 \mathrm{~nm}$; (c) Category III.

time series are distinctly different from those in Fig. 3a. Concentrations began to increase after ozone was introduced, and concentrations of both the $>20 \mathrm{~nm}$ particles and the Category II compounds reach peak values about $1 \mathrm{~h}$ after the $10-20 \mathrm{~nm}$ particles and Category I compounds reach their peak values, and decrease gradually thereafter. This suggests that these products are both first of $\alpha$-pinene ozonolysis and later-generation products formed through further $\mathrm{OH}$ radical reactions. Figure $3 \mathrm{c}$ is a time series plot for a typical Category III compound. These compounds increase steadily throughout the $20 \mathrm{~h}$ experiment, which is likely due to the fact that their production rate is only slightly greater than their loss rate. Category III compounds are not correlated with particle concentrations in any size interval. Because they accumulate over time, we infer that Category III compounds are a mixture of first- and later-generation products that are contributed from both $\alpha$-pinene ozonolysis and further $\mathrm{OH}$ radical reactions. Category III compounds might also result from further heterogeneous oxidation of lowvolatility compounds such as Category I compounds (Kroll et al., 2011). For example, particles might provide sufficient surface area for heterogeneous reactions after $2 \mathrm{~h}$ when oxidant levels are high (Fig. 1c).

Figure $4 \mathrm{a}-\mathrm{f}$ show six spectra in which the estimated concentrations of the neutral gas-phase compounds are plotted versus molecular weight over the 100-700 amu range during the period corresponding to points a-f in Fig. 1b. As explained above, these compounds are classified as Category I (red), II (blue), and III (gray). Only peaks whose concentrations were observably higher than background levels after addition of ozone, a total of 139 peaks (ref. Table 1, Table S2

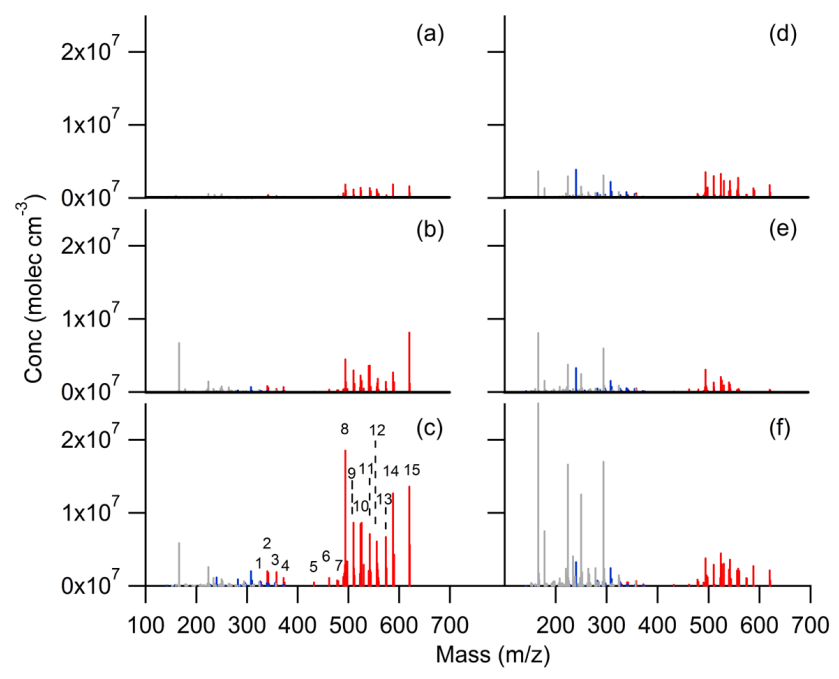

Fig. 4. Time-dependent spectra of all category products between 100 and $700 \mathrm{amu}$ measured with the Cluster CIMS for E1. (a-f) correspond to times a-f in Fig. 1b. Color codes: red - Category I products; blue - Category II products; gray - Category III products. Number $1-15$ in Fig. 4c corresponds to different peak classifications (see text for details).

and S3), are shown in these spectra. The background level of each peak was taken to be the average concentration from five consecutive scans about $2 \mathrm{~h}$ prior to ozone addition. Most peaks appear in two mass ranges: 200-400 amu and 490$630 \mathrm{amu}$. Figure $4 \mathrm{c}$ shows that concentrations of Category I compounds reach peak values when the concentration of 10 $20 \mathrm{~nm}$ particles reaches the peak values (point $\mathrm{c}$ in Figs. 1b and 3a). Figure $4 \mathrm{e}$ shows the spectrum of neutral compound concentration vs. molecular weight at the point where Category I compounds drop to their lowest levels. The Category I concentrations again pass through a second maximum when the concentration of 10-20 nm particles reaches the peak during the second particle formation event; the representative spectrum at this point is shown in Fig. 4f. Category I compounds can be further divided into 15 groups of peaks as shown in Fig. 4c. Each group contains 1 to 5 peaks as illustrated in Table 1. Ehn et al. (2012) used the APi-TOF to measure gas-phase species formed under the steady-state conditions during $\alpha$-pinene ozonolysis, and identified the elemental composition of certain products. As mentioned previously, most of the detected ions in their chamber experiments have even $m / z$ and were identified as clusters containing an $\mathrm{NO}_{3}^{-}$. In those experiments, $\mathrm{NO}_{3}^{-}$formed in the chamber from reactions of residual $\mathrm{HNO}_{3}$ with other air ions such as $\mathrm{O}_{2}^{-}$provided an in situ source of reagent ions. Ambient measurements in Hyytiälä showed that ions with odd masses were also present during the day when ambient sulfuric acid concentrations were high, and those ions were attributed to species that contain an $\mathrm{HSO}_{4}^{-}$(Ehn et al., 2012). The Cluster CIMS did detect about 13 odd $\mathrm{m} / \mathrm{z}$ ions (about one third 
Table 1. Summary of all measured Category I products for E1: ion $(\mathrm{m} / \mathrm{z})$, peak concentration of neutral species, cluster types, corresponding neutral identities, and correlation coefficients with $10-20 \mathrm{~nm}$ particles.

\begin{tabular}{|c|c|c|c|c|c|c|}
\hline \multirow[t]{2}{*}{ Group } & \multirow{2}{*}{$\begin{array}{c}\text { Ion } \\
(m / z)\end{array}$} & \multirow{2}{*}{$\begin{array}{c}\text { Peak conc. }^{\mathrm{a}} \\
\left(\mathrm{cm}^{-3}\right)\end{array}$} & \multirow{2}{*}{$\begin{array}{l}\text { Cluster } \\
\text { type }^{\mathrm{b}}\end{array}$} & \multicolumn{2}{|c|}{ Corresponding neutral $^{\mathrm{c}}$} & \multirow{2}{*}{$\begin{array}{l}\text { Correlation } \\
\text { coefficient }^{\mathrm{d}}\end{array}$} \\
\hline & & & & Mass(amu) & Formula & \\
\hline 1 & 328 & $4.8 \times 10^{5}$ & 1 & 266 & $\mathrm{C}_{9} \mathrm{H}_{14} \mathrm{O}_{9}$ & 0.65 \\
\hline 1 & 330 & $1.9 \times 10^{5}$ & NA & & & 0.50 \\
\hline 2 & 340 & $2.0 \times 10^{6}$ & 1 & 278 & $\mathrm{C}_{10} \mathrm{H}_{14} \mathrm{O}_{9}$ & 0.89 \\
\hline 2 & 342 & $1.8 \times 10^{6}$ & 1 & & $\begin{array}{c}\mathrm{C}_{9} \mathrm{H}_{12} \mathrm{O}_{10} \\
\text { or } \mathrm{C}_{10} \mathrm{H}_{16} \mathrm{O}_{9}\end{array}$ & 0.87 \\
\hline 3 & 358 & $1.9 \times 10^{6}$ & 1 & 296 & $\mathrm{C}_{10} \mathrm{H}_{16} \mathrm{O}_{10}$ & 0.87 \\
\hline 3 & 359 & $2.2 \times 10^{5}$ & NA & & & 0.53 \\
\hline 4 & 372 & $1.1 \times 10^{6}$ & 1 & 310 & $\mathrm{C}_{10} \mathrm{H}_{14} \mathrm{O}_{11}$ & 0.90 \\
\hline 4 & 373 & $2.6 \times 10^{5}$ & NA & & & 0.63 \\
\hline 4 & 374 & $6.3 \times 10^{5}$ & 1 & 312 & $\mathrm{C}_{10} \mathrm{H}_{16} \mathrm{O}_{11}$ & 0.84 \\
\hline 5 & 432 & $4.9 \times 10^{5}$ & NA & & & 0.64 \\
\hline 6 & 460 & $1.1 \times 10^{6}$ & NA & & & 0.66 \\
\hline 7 & 478 & $9.2 \times 10^{5}$ & NA & & & 0.78 \\
\hline 7 & 480 & $6.5 \times 10^{5}$ & 1 & 418 & $\mathrm{C}_{18} \mathrm{H}_{26} \mathrm{O}_{11}$ & 0.46 \\
\hline 8 & 490 & $1.6 \times 10^{6}$ & 1 & 428 & $\mathrm{C}_{14} \mathrm{H}_{20} \mathrm{O}_{15}$ & 0.69 \\
\hline 8 & 492 & $1.7 \times 10^{6}$ & NA & & & 0.55 \\
\hline 8 & 493 & $2.9 \times 10^{6}$ & NA & & & 0.84 \\
\hline 8 & 494 & $1.9 \times 10^{7}$ & 1 & 432 & $\mathrm{C}_{19} \mathrm{H}_{28} \mathrm{O}_{11}$ & 0.88 \\
\hline 8 & 495 & $3.4 \times 10^{6}$ & 2 & & & 0.76 \\
\hline 8 & 496 & $2.3 \times 10^{6}$ & NA & & & 0.61 \\
\hline 8 & 498 & $3.3 \times 10^{6}$ & NA & & & 0.67 \\
\hline 9 & 510 & $8.6 \times 10^{6}$ & 1 & 448 & $\mathrm{C}_{20} \mathrm{H}_{32} \mathrm{O}_{11}$ & 0.70 \\
\hline 9 & 511 & $2.5 \times 10^{6}$ & 2 & & & 0.72 \\
\hline 9 & 512 & $2.1 \times 10^{6}$ & NA & & & 0.50 \\
\hline 10 & 523 & $1.8 \times 10^{6}$ & NA & & & 0.66 \\
\hline 10 & 524 & $1.0 \times 10^{7}$ & 1 & 462 & $\mathrm{C}_{20} \mathrm{H}_{30} \mathrm{O}_{12}$ & 0.68 \\
\hline 10 & 525 & $8.3 \times 10^{6}$ & 2 & & & 0.64 \\
\hline 10 & 526 & $8.7 \times 10^{6}$ & 1 & 464 & $\mathrm{C}_{19} \mathrm{H}_{28} \mathrm{O}_{13}$ & 0.74 \\
\hline 10 & 530 & $3.0 \times 10^{6}$ & 1 & 468 & $\mathrm{C}_{18} \mathrm{H}_{28} \mathrm{O}_{14}$ & 0.43 \\
\hline 11 & 540 & $3.8 \times 10^{6}$ & 1 & 478 & $\mathrm{C}_{20} \mathrm{H}_{30} \mathrm{O}_{13}$ & 0.52 \\
\hline 11 & 541 & $2.4 \times 10^{6}$ & 2 & & & 0.67 \\
\hline 11 & 542 & $1.0 \times 10^{7}$ & 1 & 480 & $\mathrm{C}_{20} \mathrm{H}_{32} \mathrm{O}_{13}$ & 0.87 \\
\hline 11 & 543 & $3.9 \times 10^{6}$ & 2 & & & 0.74 \\
\hline 11 & 544 & $2.0 \times 10^{6}$ & NA & & & 0.56 \\
\hline 12 & 556 & $6.4 \times 10^{6}$ & 1 & 494 & $\mathrm{C}_{20} \mathrm{H}_{30} \mathrm{O}_{14}$ & 0.73 \\
\hline 12 & 557 & $3.1 \times 10^{6}$ & 2 & & & 0.68 \\
\hline 12 & 558 & $3.5 \times 10^{6}$ & NA & & & 0.48 \\
\hline 12 & 559 & $1.7 \times 10^{6}$ & 2 & & & 0.57 \\
\hline 12 & 560 & $2.0 \times 10^{6}$ & NA & & & 0.48 \\
\hline 13 & 574 & $8.0 \times 10^{6}$ & 1 & 512 & $\mathrm{C}_{20} \mathrm{H}_{32} \mathrm{O}_{15}$ & 0.78 \\
\hline 13 & 575 & $2.6 \times 10^{6}$ & 2 & & & 0.56 \\
\hline 14 & 588 & $1.3 \times 10^{7}$ & 1 & 526 & $\mathrm{C}_{20} \mathrm{H}_{30} \mathrm{O}_{16}$ & 0.88 \\
\hline 14 & 590 & $4.4 \times 10^{6}$ & NA & & & 0.73 \\
\hline 15 & 620 & $1.4 \times 10^{7}$ & 1 & 558 & $\mathrm{C}_{20} \mathrm{H}_{30} \mathrm{O}_{18}$ & 0.86 \\
\hline 15 & 621 & $5.6 \times 10^{6}$ & 2 & & & 0.67 \\
\hline
\end{tabular}

a concentration: background subtracted peak concentration $\left(\right.$ in $\left.\mathrm{cm}^{-3}\right)$ at time $\mathrm{c}$ in Fig. 1b;

b cluster types: type 1 contains an $\mathrm{NO}_{3}^{-}$(from Ehn et al., 2012); type 2 possibly contains an $\mathrm{NO}_{3}^{-} \cdot \mathrm{HNO}_{3}$;

c from Ehn et al. (2012);

$\mathrm{d}$ correlation was performed with the concentration of $10-20 \mathrm{~nm}$ particles for time period $t=0-10 \mathrm{~h}$ in Fig. $1 \mathrm{~b}(t=0$ was defined as the time when ozone was added to the chamber). 


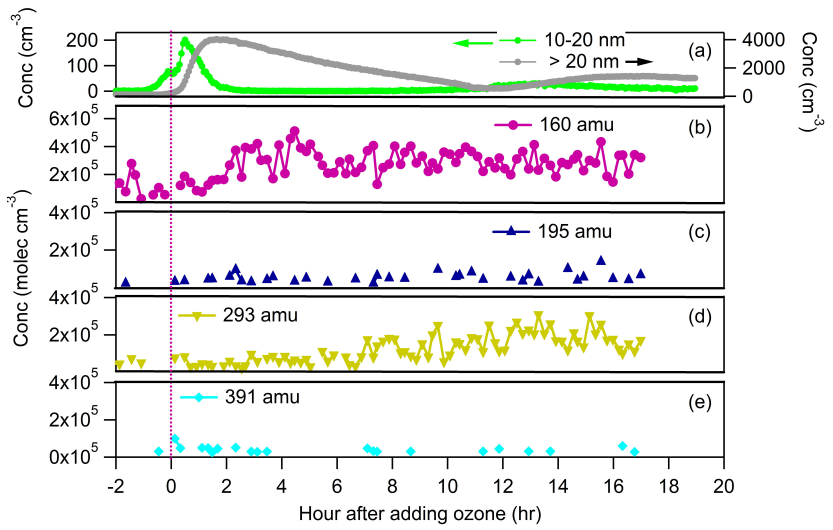

Fig. 5. (a) Time-dependent concentrations of ions corresponding to sulfuric acid and its clusters containing up to $4 \mathrm{H}_{2} \mathrm{SO}_{4}$, along with the concentrations of 10-20 nm particles and $>20 \mathrm{~nm}$ particles for E1 (b $160 \mathrm{amu}$, monomer; c $195 \mathrm{amu}$, dimer; d $293 \mathrm{amu}$, likely organic species other than trimer; e $391 \mathrm{amu}$, tetramer).

of the 44 ions in Table 1) in Category I products. Because nitrate dimers were employed as reagent ions in chemical ionization and nitric acid concentrations were elevated in the ionization zone, those odd $\mathrm{m} / \mathrm{z}$ ions were most likely from the addition of one more nitric acid ( $63 \mathrm{amu}$ ) to the even $\mathrm{m} / \mathrm{z}$ clusters (containing an $\mathrm{NO}_{3}^{-}$), for example, $557 \mathrm{amu}$ from $494 \mathrm{amu}, 621 \mathrm{amu}$ from $558 \mathrm{amu}$, etc. (Table 1). Our elemental composition assignments in Table 1 are based on species identified by Ehn et al. using high-resolution mass spectrometry (Ehn et al., 2012). Table 1 also shows the corresponding neutral formulae and their molecular weights, as well as their correlation coefficients with $10-20 \mathrm{~nm}$ particles. A few compounds having correlation coefficients smaller than 0.5 (see column 7) are still included in Category I compounds because their time-dependent concentrations follow similar trends as those with correlation coefficients greater than 0.5.

Four HOM compounds $\left(\mathrm{C}_{10} \mathrm{H}_{14} \mathrm{O}_{7}, \quad \mathrm{C}_{10} \mathrm{H}_{14} \mathrm{O}_{9}\right.$, $\left.\mathrm{C}_{10} \mathrm{H}_{16} \mathrm{O}_{9}, \mathrm{C}_{10} \mathrm{H}_{16} \mathrm{O}_{11}\right)$ in the Ehn et al. study were identified as the most abundant products, clustering with the reagent ion $\mathrm{NO}_{3}^{-}$with peaks at 308, 340, 342, and $372 \mathrm{amu}$ (Ehn et al., 2012). The Cluster CIMS measurements also show that during particle nucleation those products are among the most abundant. Based on their time-dependent profiles and their correlation with particles, one (308 amu) belongs to Category II and the rest (340, 342, and $372 \mathrm{amu})$ belong to Category I compounds. The intensities of Category I compounds in the 300-400 amu range are generally about twice those in the 490-630 amu range (corresponding to neutral masses of 430-560 amu); however, after massdependent sensitivities of the Cluster CIMS are applied (Fig. S4), the estimated concentrations of the latter are much higher than the former (about 20 times) because the Cluster CIMS sensitivities drop rapidly for ions larger than $400 \mathrm{amu}$ (Zhao et al., 2010). The peak and steady-state concentrations for the sum of Category I compounds are estimated to be about $1.6 \times 10^{8}$ and $2.2 \times 10^{7} \mathrm{~cm}^{-3}$ respectively, predominately contributed from products in the 490-630 amu range (group 8-15 in Fig. 4c). Among them, there is one ion in each group that has much higher concentration than the adjacent ions except group 10, which has high concentrations in the adjacent three peaks (524, $525,526 \mathrm{amu}$ ) (Table 1). The sum of the concentrations of those species comprises more than $70 \%$ of the total Category I products. We estimate the overall uncertainty in concentrations of Category I compounds to be about a factor of 5, mainly influenced by the uncertainty of the mass-dependent sensitivities in the high mass range (i.e., 400-700 amu) and the estimated ion-molecule reaction time. Compared to ambient measurements, uncertainties associated with background identification and subtraction are minor because of low background levels relative to the signals after ozone addition (Jiang et al., 2011). In comparison, a steady-state concentration of about $10^{6}-10^{7} \mathrm{~cm}^{-3}$ for the neutral HOM products was estimated in Ehn et al. (2012), significantly lower than those estimated in this study under similar precursor concentrations but a much lower humidity (less than 1\%) than that in Eh et al. (about $63 \%)$.

\subsection{Contribution of residual sulfuric acid vapor to particle nucleation}

Figure 5 shows the time series plots of concentrations corresponding to the sulfuric acid monomer (160 amu, Fig. 5b), dimer (195 amu, Fig. 5c), trimer (293 amu, Fig. 5d), and tetramer (391 amu, Fig. 5e), along with the $10-20 \mathrm{~nm}$ and $>20 \mathrm{~nm}$ particles (Fig. 5a). The source of sulfuric acid was not known, but it was likely attributed to reactions of residual $\mathrm{SO}_{2}$ with $\mathrm{OH}$ radicals that were generated during the ozonolysis. Residual $\mathrm{SO}_{2}$ was likely present in the zero air since the $\mathrm{SO}_{2}$ was not scrubbed before the house compressed air was delivered to the zero air generator. During the intense formation event of $10-20 \mathrm{~nm}$ particles, sulfuric acid monomer concentrations increased steadily, but its maximum level (about $5.5 \times 10^{5} \mathrm{~cm}^{-3}$ at about $4 \mathrm{~h}$ ) occurred about $3.5 \mathrm{~h}$ after the peak concentration of the 10-20 nm particles. The concentration of the cluster corresponding to $293 \mathrm{amu}$ varied between $5 \times 10^{4}$ and $3 \times 10^{5} \mathrm{~cm}^{-3}$. However, this ion is unlikely attributed to sulfuric acid trimers because concentrations of ions associated with sulfuric acid dimers and tetramers were barely higher than their background levels. Concentrations of the measured sulfuric acid clusters containing 2-4 $\mathrm{H}_{2} \mathrm{SO}_{4}$ molecules were hence below the detection limits $\left(<2 \times 10^{4} \mathrm{~cm}^{-3}\right)$.

Sulfuric acid concentrations were estimated to be below $2.0 \times 10^{5} \mathrm{~cm}^{-3}$ during intense particle nucleation. We estimated an upper limit for sulfuric acid concentrations of about $3 \times 10^{5} \mathrm{~cm}^{-3}$, with a $\pm 50 \%$ uncertainty. At these concentrations, no nucleation has been reported either in laboratory 
or ambient measurements. However, if the available measured nucleation rates are extrapolated down to sulfuric acid concentrations of $\sim 3 \times 10^{5} \mathrm{~cm}^{-3}$ observed in this study, an upper limit of about $0.3-0.5 \mathrm{~cm}^{-3} \mathrm{~s}^{-1}$ is obtained (Chen et al., 2012; Zollner et al., 2012). We observed values of $J_{10 \mathrm{~nm}}$ of about 0.42 and $0.038 \mathrm{~cm}^{-3} \mathrm{~s}^{-1}$, respectively, for the first and second events from the SMPS measurements (Fig. 1a). The nucleation rates are not known because only particles larger than $10 \mathrm{~nm}$ were measured. The SMPS measurements showed an initial modal growth rate of about $36 \mathrm{~nm} \mathrm{~h}^{-1}$ for the first hour (between 1 and $2 \mathrm{~h}$ in Fig. 1b) after detection of $10 \mathrm{~nm}$ particles. Subsequently, the modal growth rate decreased until it reached a value of about $28 \mathrm{~nm} \mathrm{~h}^{-1}$. If the growth of initial nuclei (from 1 to $10 \mathrm{~nm}$ ) follows similar trends, then a growth rate much larger than $36 \mathrm{~nm} \mathrm{~h}^{-1}$ can be expected for that size range. In addition, the condensation sink is low at the start of particle nucleation. It is hence reasonable to assume that the nucleation rate is close to $J_{10 \mathrm{~nm}}$ (McMurry et al., 2005) and falls within the extrapolated upper limit of the nucleation rate at the measured concentration of residual sulfuric acid vapor in the chamber.

Although the total concentration of Category I products is several orders of magnitude higher than that of the residual sulfuric acid vapor and the concentrations of sulfuric acid clusters (dimers, trimers, tetramers, etc.) were below the detection limit of the Cluster CIMS, the role of sulfuric acid in influencing particle nucleation cannot be totally ruled out. It is possible that particle nucleation is initiated by formation of sulfuric acid clusters and the subsequent rapid growth is due to condensation of the oxidation organic products. The growth rate enhancement factor, $\Gamma$, is the ratio of the observed particle growth rate to the growth rate due to sulfuric acid vapor alone (Kuang et al., 2010). A $\Gamma$ value of about 1600 was estimated for the first hour after detection of $10 \mathrm{~nm}$ particles in the first event shown in Fig. 1a, which demonstrates that organic products dominate particle growth.

\subsection{Mechanisms for particle growth}

Low-volatility carboxylic acids (C8-C10) have been identified in the particulate phase as the major components of secondary organic aerosols formed from $\alpha$-pinene ozonolysis (Yasmeen et al., 2010; Claeys et al., 2009), including terpenylic acid (172 amu), cis-pinonic acid (184 amu), and pinic acid (186 amu). Those carboxylic acids were found to be the major constituents of the 10 and $20 \mathrm{~nm}$ particles from $\alpha$-pinene ozonolysis in a flow reactor (Winkler et al., 2012). Winkler et al. estimated a saturation vapor pressure on the order of $10^{-11} \mathrm{~atm}$ or less for compounds responsible for growth of particles between $4-30 \mathrm{~nm}$ and $10^{-9}$ atm for compounds responsible for growth of particles larger than $30 \mathrm{~nm}$, within the lower end of the previous measured saturation vapor pressures of $\mathrm{C} 8-\mathrm{C} 18$ monocarboxylic acids $\left(10^{-3} \sim 10^{-11} \mathrm{~atm}\right)$ (Cappa et al., 2008; Tao and McMurry, 1989). Donahue et al. (2011) predicted a broad range of volatilities (hence saturation vapor pressures) for oxidized organics containing up to 30 carbons with different functional groups. We did not detect significant concentrations of carboxylic acid monomers in our gas-phase measurements using nitrate dimer ion as the reagent ion; instead, we observed highly oxidized high-molecular-weight compounds such as Category I products, predominantly in the 430-560 amu range. Some Category I products are possible dimers of products in a lower mass range (100-300 amu), forming via hydrogen bonding or covalent bonding that loses one water molecule, or other possible formation pathways, while some of them are high-molecular-weight compounds rather than dimers (Fig. S6). However, high mass resolution is needed to confirm the above statement. The current unit mass resolution of the Cluster CIMS cannot definitely identify the molecular composition of those compounds. The carboxylic acid monomers detected in Winkler et al. (2012) are likely fragments of high-molecular-weight compounds due to thermal decomposition of particulate species during resistive heating of particles in the TDCIMS measurements (Hall and Johnston, 2012b). The highly oxidized Category I products likely have even lower saturation vapor pressures $\left(\sim 10^{-14}-10^{-12} \mathrm{~atm}\right)$ than those estimated in Winkler et al. (2012) due to their higher molecular weights and higher oxygen contents. Hence they can partition into particles and help them grow to overcome the Kelvin effect during the early stages of particle growth, as indicated by their high correlations with the measured $10-20 \mathrm{~nm}$ particles. The total peak concentration of Category I compounds is approximately $1.6 \times 10^{8} \mathrm{~cm}^{-3}$, about a factor of 2 lower than what is required for growth of particles in the first hour after detection of $10 \mathrm{~nm}$ particles (see Supplement Sect. III). Considering the uncertainty of the concentration of Category I products and the required concentration estimated for the observed growth rate, it is possible that Category I products contribute to the rapid growth of particles in the first hour after detection of $10 \mathrm{~nm}$ particles. Demonstrating this with certainty would require identifying the composition of the initial nucleated particles.

The steady-state concentration of all Category II compounds is about $8 \times 10^{6} \mathrm{~cm}^{-3}$, three times lower than Category I compound concentrations $\left(\sim 2.2 \times 10^{7} \mathrm{~cm}^{-3}\right)$. The total steady-state concentration of both Category I and II compounds is at least one order of magnitude lower than required for the observed particle growth rates of $28 \mathrm{~nm} \mathrm{~h}^{-1}$, indicating that they are probably not the dominant species responsible for the growth of larger $(>20 \mathrm{~nm})$ particles. The measured peak concentration of sulfuric acid vapor is about $5 \times 10^{5} \mathrm{~cm}^{-3}$, several orders of magnitude lower than the minimum concentration required for particle growth rates of the first or second events (see Supplement Sect. III, Table S5). We therefore conclude that particle growth is not significantly influenced by sulfuric acid vapor in these experiments. 
The nitrate dimer ion was used as the reagent ion for E1 and E2 in this study, and it has high selectivity for ionization of the reaction products. Oxidation products with less electronegativity might not be measured or might be detected with a lower sensitivity (e.g., category II and III) when the nitrate dimer ion is used as the reagent ion. An exploratory experiment (E3, Table S1) with acetate dimer ion as the reagent ion was performed to measure less electronegative compounds. A much higher total steady-state concentration (about $6-8 \times 10^{8} \mathrm{~cm}^{-3}$ ) of all products that arise from $\alpha$ pinene ozonolysis was measured. The identification of those products is not possible given the $1 \mathrm{amu}$ resolution of the Cluster CIMS; however, it can be speculated that those products might encompass compounds such as less electronegative carboxylic acids, esters, or even carbonyls that are present in the gas phase with much higher concentrations and that might contribute more significantly to particle growth, as observed in measurements by Winkler et al. (2012). Those compounds may contribute to particle growth by particulatephase reactions such as acid-catalyzed reactions or polymerization (e.g., Wang et al., 2010b; Zhao et al., 2006, 2005; Hall and Johnston, 2012a; Hall and Johnston, 2011). Alternatively, reactions between carboxylic acid and basic gases on or within freshly nucleated particles may also contribute to nanoparticle growth (Barsanti et al., 2009; Smith et al., 2010; Yli-Yuuti et al., 2013). It is likely that more oxidation products would be detected if acetate dimer ion were used as the reagent ion. Contributions of those products to the growth of larger $(>20 \mathrm{~nm})$ particles will be studied in the future. Future studies will require simultaneous measurements in the gas and particle phases along with models that use such information to explain the dependence of particle growth rate on gas-phase concentrations.

Our experiments were performed with $\mathrm{NO}_{\mathrm{x}}$ and $\mathrm{H}_{2} \mathrm{O}$ concentrations that are significantly below typical ambient levels. Results from both chamber experiments (Eddingsaas et al., 2012; Lee at al., 2011) and model simulations (Lane et al., 2008) showed that the SOA yields are higher under low$\mathrm{NO}_{\mathrm{x}}$ conditions than under high- $\mathrm{NO}_{\mathrm{x}}$ conditions because of the change in the product distributions. Low-volatility products such as carboxylic acids were formed under low- $\mathrm{NO}_{\mathrm{x}}$ conditions, while more volatile products such as carbonyls, alcohols, and organic nitrates are generated under high- $\mathrm{NO}_{\mathrm{x}}$ conditions. Similarly, water vapor plays important roles in the product distributions of terpene oxidation and hence affects the aerosol mass yields (Jonsson et al., 2008; Fick et al., 2003). It is hence important to understand how humidity and $\mathrm{NO}_{\mathrm{x}}$ affect the chemical processes responsible for particle nucleation and growth.

\section{Summary}

Chamber experiments of $\alpha$-pinene ozonolysis with ambient levels of precursors were performed under low- $\mathrm{NO}_{\mathrm{x}}$ and dry conditions. The time-dependent concentrations of gas-phase reaction products were measured with the Cluster CIMS using nitrate dimers as reagent ions. The observable products were classified into two categories, which we found were correlated with particle nucleation (I) and growth (II). A third category (III) was not clearly correlated with either process, but could be lower-molecular-weight decomposition products from the oxidation of Category I and II species. The nucleation-relevant products were found to be mainly in the high molecular weight range, with molecular weights in the 430-560 amu range. The growth-relevant products, which were well correlated with concentrations of particles larger than $20 \mathrm{~nm}$, were in the 140-380 amu range. Measurements from this study suggest that for this chemical system, organic compounds were likely responsible for nucleation, although sulfuric acid vapor cannot be totally ruled out. The effects of $\mathrm{NO}_{\mathrm{x}}$ and humidity on the formation of Category I products warrant further studies.

\section{Supplementary material related to this article is available online at: http://www.atmos-chem-phys.net/13/ 7631/2013/acp-13-7631-2013-supplement.pdf.}

Acknowledgements. We thank National Science Foundation (NSF) award AGS 1068201 for supporting the chamber experiments performed at National Center for Atmospheric Research (NCAR). P.H. McMurray was supported by a Guggenheim Fellowship. The authors acknowledge James Greenburg for PTR-MS measurements of the gas-phase precursor and reaction products. The National Center for Atmospheric Research is sponsored by the National Science Foundation. Additional funding for this research was provided by the US Department of Energy grant no. DE-SC0006861. J.S. Smith acknowledges funding from the Finnish Academy grant no. 251007 and US NSF grant no. 0919317.

Edited by: N. M. Donahue

\section{References}

Barsanti, K. C., McMurry, P. H., and Smith, J. N.: The potential contribution of organic salts to new particle growth, Atmos. Chem. Phys., 9, 2949-2957, doi:10.5194/acp-9-2949-2009, 2009.

Berndt, T., Stratmann, F., Sipilä, M., Vanhanen, J., Petäjä, T., Mikkilä, J., Grüner, A., Spindler, G., Lee Mauldin III, R., Curtius, J., Kulmala, M., and Heintzenberg, J.: Laboratory study on new particle formation from the reaction $\mathrm{OH}+\mathrm{SO}_{2}$ : influence of experimental conditions, $\mathrm{H}_{2} \mathrm{O}$ vapour, $\mathrm{NH}_{3}$ and the amine tert-butylamine on the overall process, Atmos. Chem. Phys., 10, 7101-7116, doi:10.5194/acp-10-7101-2010, 2010.

Boy, M., Karl, T., Turnipseed, A., Mauldin, R. L., Kosciuch, E., Greenberg, J., Rathbone, J., Smith, J., Held, A., Barsanti, K., Wehner, B., Bauer, S., Wiedensohler, A., Bonn, B., Kulmala, M., and Guenther, A.: New particle formation in the Front Range of 
the Colorado Rocky Mountains, Atmos. Chem. Phys., 8, 15771590, doi:10.5194/acp-8-1577-2008, 2008.

Breitner, S., Liu, L. Q., Cyrys, J., Bruske, I., Franck, U., Schlink, U., Leitte, A. M., Herbarth, O., Wiedensohler, A., Wehner, B., Hu, M., Pan, X. C., Wichmann, H. E., and Peters, A.: Sub-micrometer particulate air pollution and cardiovascular mortality in Beijing, China, Sci. Total Environ., 409, 5196-5204, 2011.

Bzdek, B. R. and Johnston, M. V.: New Particle Formation and Growth in the Troposphere, Anal. Chem., 82, 7871-7878, 2010.

Cahill, T. M., Seaman, V. Y., Charles, M. J., Holzinger, R., and Goldstein, A. H.: Secondary organic aerosols formed from oxidation of biogenic volatile organic compounds in the Sierra Nevada Mountains of California, J. Geophys. Res., 111, D16312, doi:10.1029/2006JD007178, 2006.

Cappa, C. D., Lovejoy, E. R., and Ravishankara, A. R.: Evaporation rates and vapor pressures of the even-nunibered C8-C18 monocarboxylic acids, J. Phys. Chem. A, 112, 3959-3964, 2008.

Chen, M., Titcombe, M., Jiang, J. K., Jen, C., Kuang, C. A., Fischer, M. L., Eisele, F. L., Siepmann, J. I., Hanson, D. R., Zhao, J., and McMurry, P. H.: Acid-base chemical reaction model for nucleation rates in the polluted atmospheric boundary layer, P. Natl. Acad. Sci. USA, 109, 18713-18718, 2012.

Chen, X. and Hopke, P. K.: Secondary organic aerosol from alphapinene ozonolysis in dynamic chamber system, Indoor Air, 19, 335-345, 2009.

Chen, X., Hopke, P. K., and Carter, W. P. L.: Secondary organic aerosol from ozonolysis of biogenic volatile organic compounds: chamber studies of particle and reactive oxygen species formation, Environ. Sci. Technol., 45, 276-282, 2011.

Claeys, M., Iinuma, Y., Szmigielski, R., Surratt, J. D., Blockhuys, F., Van Alsenoy, C., Boge, O., Sierau, B., Gomez-Gonzalez, Y., Vermeylen, R., Van der Veken, P., Shahgholi, M., Chan, A. W. H., Herrmann, H., Seinfeld, J. H., and Maenhaut, W.: Terpenylic acid and related compounds from the oxidation of alpha-pinene: Implications for new particle formation and growth above forests, Environ. Sci. Technol., 43, 6976-6982, 2009.

DePalma, J. W., Bzdek, B. R., Doren, D. J., and Johnston, M. V.: Structure and energetics of nanometer size clusters of sulfuric acid with ammonia and dimethylamine, J. Phys. Chem. A, 116, 1030-1040, 2012.

Donahue, N. M., Epstein, S. A., Pandis, S. N., and Robinson, A. L.: A two-dimensional volatility basis set: 1. organic-aerosol mixing thermodynamics, Atmos. Chem. Phys., 11, 3303-3318, doi:10.5194/acp-11-3303-2011, 2011.

Donahue, N. M., Henry, K. M., Mentel, T. F., Kiendler-Scharr, A., Spindler, C., Bohn, B., Brauers, T., Dorn, H. P., Fuchs, H., Tillmann, R., Wahner, A., Saathoff, H., Naumann, K. H., Mohler, O., Leisner, T., Muller, L., Reinnig, M. C., Hoffmann, T., Salo, K., Hallquist, M., Frosch, M., Bilde, M., Tritscher, T., Barmet, P., Praplan, A. P., DeCarlo, P. F., Dommen, J., Prevot, A. S. H., and Baltensperger, U.: Aging of biogenic secondary organic aerosol via gas-phase $\mathrm{OH}$ radical reactions, P. Natl. Acad. Sci. USA, 109, 13503-13508, 2012.

Eddingsaas, N. C., Loza, C. L., Yee, L. D., Chan, M., Schilling, K. A., Chhabra, P. S., Seinfeld, J. H., and Wennberg, P. O.: $\alpha$-pinene photooxidation under controlled chemical conditions -Part 2: SOA yield and composition in low- and high- $\mathrm{NO}_{\mathrm{x}}$ environments, Atmos. Chem. Phys., 12, 7413-7427, doi:10.5194/acp-12-74132012, 2012.
Ehn, M., Kleist, E., Junninen, H., Petäjä, T., Lönn, G., Schobesberger, S., Dal Maso, M., Trimborn, A., Kulmala, M., Worsnop, D. R., Wahner, A., Wildt, J., and Mentel, Th. F.: Gas phase formation of extremely oxidized pinene reaction products in chamber and ambient air, Atmos. Chem. Phys., 12, 5113-5127, doi:10.5194/acp-12-5113-2012, 2012.

Erupe, M. E., Viggiano, A. A., and Lee, S.-H.: The effect of trimethylamine on atmospheric nucleation involving $\mathrm{H}_{2} \mathrm{SO}_{4}$, Atmos. Chem. Phys., 11, 4767-4775, doi:10.5194/acp-11-47672011, 2011.

Fick, J., Pommer, L., Nilsson, C., and Andersson, B.: Effect of OH radicals, relative humidity, and time on the composition of the products formed in the ozonolysis of alpha-pinene, Atmos. Environ., 37, 4087-4096, 2003.

Forester, C. D. and Wells, J. R.: Hydroxyl radical yields from reactions of terpene mixtures with ozone, Indoor Air, 21, 400-409, doi:10.1111/j.1600-0668.2011.00718.x, 2011.

Franck, U., Odeh, S., Wiedensohler, A., Wehner, B., and Herbarth, O.: The effect of particle size on cardiovascular disorders - The smaller the worse, Sci. Total Environ., 409, 4217-4221, 2011.

Guenther, A., Hewitt, C. N., Erickson, D., Fall, R., Geron, C., Graedel, T., Harley, P., Klinger, L., Lerdau, M., McKay, W. A., Pierce, T., Scholes, B., Steinbrecher, R., Tallamraju, R., Taylor, J., and Zimmerman, P.: A global-model of natural volatile organic-compound emissions, J. Geophys. Res., 100, 88738892, 1995.

Hall, W. A. and Johnston, M. V.: Oligomer content of alpha-pinene secondary organic aerosol, Aerosol Sci. Technol., 45, 37-45, 2011.

Hall, W. A. and Johnston, M. V.: Oligomer formation pathways in secondary organic aerosol from MS and MS/MS measurements with high mass accuracy and resolving power, J. Am. Soc. Mass Spectr., 23, 1097-1108, 2012a.

Hall, W. A. and Johnston, M. V.: The thermal-stability of oligomers in alpha-pinene secondary organic aerosol, Aerosol Sci. Technol., 46, 983-989, 2012b.

Hao, L. Q., Romakkaniemi, S., Yli-Pirilä, P., Joutsensaari, J., Kortelainen, A., Kroll, J. H., Miettinen, P., Vaattovaara, P., Tiitta, P., Jaatinen, A., Kajos, M. K., Holopainen, J. K., Heijari, J., Rinne, J., Kulmala, M., Worsnop, D. R., Smith, J. N., and Laaksonen, A.: Mass yields of secondary organic aerosols from the oxidation of ?-pinene and real plant emissions, Atmos. Chem. Phys., 11, 1367-1378, doi:10.5194/acp-11-1367-2011, 2011.

Heaton, K. J., Dreyfus, M. A., Wang, S., and Johnston, M. V.: Oligomers in the early stage of biogenic secondary organic aerosol formation and growth, Environ. Sci. Technol., 41, 61296136, 2007.

Herckes, P., Engling, G., Kreidenweis, S. M., and Collett, J. L.: Particle size distributions of organic aerosol constituents during the 2002 Yosemite Aerosol Characterization Study, Environ. Sci. Technol., 40, 4554-4562, 2006.

Hyder, M., Genberg, J., Sandahl, M., Swietlicki, E., and Jonsson, J. A.: Yearly trend of dicarboxylic acids in organic aerosols from south of Sweden and source attribution, Atmos. Environ., 57, 197-204, 2012.

Iida, K., Stolzenburg, M. R., McMurry, P. H., and Smith, J. N.: Estimating nanoparticle growth rates from sizedependent charged fractions: Analysis of new particle formation events in Mexico City, J. Geophys. Res., 113, D05207, 
dio:10.1029/2007JD009260, 2008.

Jiang, J. K., Zhao, J., Chen, M. D., Eisele, F. L., Scheckman, J., Williams, B. J., Kuang, C. A., and McMurry, P. H.: First Measurements of Neutral Atmospheric Cluster and 1-2 nm Particle Number Size Distributions During Nucleation Events, Aerosol Sci. Technol., 45, II-V, doi:10.1080/02786826.2010.546817, 2011.

Jimenez, J. L., Canagaratna, M. R., Donahue, N. M., Prevot, A. S. H., Zhang, Q., Kroll, J. H., DeCarlo, P. F., Allan, J. D., Coe, H., Ng, N. L., Aiken, A. C., Docherty, K. S., Ulbrich, I. M., Grieshop, A. P., Robinson, A. L., Duplissy, J., Smith, J. D., Wilson, K. R., Lanz, V. A., Hueglin, C., Sun, Y. L., Tian, J., Laaksonen, A., Raatikainen, T., Rautiainen, J., Vaattovaara, P., Ehn, M., Kulmala, M., Tomlinson, J. M., Collins, D. R., Cubison, M. J., Dunlea, E. J., Huffman, J. A., Onasch, T. B., Alfarra, M. R., Williams, P. I., Bower, K., Kondo, Y., Schneider, J., Drewnick, F., Borrmann, S., Weimer, S., Demerjian, K., Salcedo, D., Cottrell, L., Griffin, R., Takami, A., Miyoshi, T., Hatakeyama, S., Shimono, A., Sun, J. Y., Zhang, Y. M., Dzepina, K., Kimmel, J. R., Sueper, D., Jayne, J. T., Herndon, S. C., Trimborn, A. M., Williams, L. R., Wood, E. C., Middlebrook, A. M., Kolb, C. E., Baltensperger, U., and Worsnop, D. R.: Evolution of Organic Aerosols in the Atmosphere, Science, 326, 1525-1529, 2009.

Jonsson, A. M., Hallquist, M., and Ljungstrom, E.: Influence of $\mathrm{OH}$ scavenger on the water effect on secondary organic aerosol formation from ozonolysis of limonene, Delta(3)-carene, and alphapinene, Environ. Sci. Technol., 42, 5938-5944, 2008.

Kamens, R. M., Gery, M. W., Jeffries, H. E., Jackson, M., and Cole, E. I.: Ozone-isoprene reactions-product formation and aerosol potential, Int. J. Chem. Kinet., 14, 955-975, 1982.

Kerminen, V. M., Lihavainen, H., Komppula, M., Viisanen, Y., and Kulmala, M.: Direct observational evidence linking atmospheric aerosol formation and cloud droplet activation, Geophys. Res. Lett., 32, L14803, doi:10.1029/2005GL023130, 2005.

Kirkby, J., Curtius, J., Almeida, J., Dunne, E., Duplissy, J., Ehrhart, S., Franchin, A., Gagne, S., Ickes, L., Kurten, A., Kupc, A., Metzger, A., Riccobono, F., Rondo, L., Schobesberger, S., Tsagkogeorgas, G., Wimmer, D., Amorim, A., Bianchi, F., Breitenlechner, M., David, A., Dommen, J., Downard, A., Ehn, M., Flagan, R. C., Haider, S., Hansel, A., Hauser, D., Jud, W., Junninen, H., Kreissl, F., Kvashin, A., Laaksonen, A., Lehtipalo, K., Lima, J., Lovejoy, E. R., Makhmutov, V., Mathot, S., Mikkila, J., Minginette, P., Mogo, S., Nieminen, T., Onnela, A., Pereira, P., Petaja, T., Schnitzhofer, R., Seinfeld, J. H., Sipila, M., Stozhkov, Y., Stratmann, F., Tome, A., Vanhanen, J., Viisanen, Y., Vrtala, A., Wagner, P. E., Walther, H., Weingartner, E., Wex, H., Winkler, P. M., Carslaw, K. S., Worsnop, D. R., Baltensperger, U., and Kulmala, M.: Role of sulphuric acid, ammonia and galactic cosmic rays in atmospheric aerosol nucleation, Nature, 476, 429-433, 2011.

Kroll, J. H., Sahay, S. R., Anderson, J. G., Demerjian, K. L., and Donahue, N. M.: Mechanism of HOx formation in the gas-phase ozone-alkene reaction. 2. Prompt versus thermal dissociation of carbonyl oxides to form OH, J. Phys. Chem. A, 105, 4446-4457, 2001.

Kroll, J. H., Donahue, N. M., Jimenez, J. L., Kessler, S. H., Canagaratna, M. R., Wilson, K. R., Altieri, K. E., Mazzoleni, L. R., Wozniak, A. S., Bluhm, H., Mysak, E. R., Smith, J. D., Kolb, C. E., and Worsnop, D. R.: Carbon oxidation state as a metric for describing the chemistry of atmospheric organic aerosol, Nat.
Chem., 3, 133-139, 2011.

Kuang, C., McMurry, P. H., McCormick, A. V., and Eisele, F. L.: Dependence of nucleation rates on sulfuric acid vapor concentration in diverse atmospheric locations, J. Geophys. Res., 113, D10209, doi:10.1029/2007JD009253, 2008.

Kuang, C., McMurry, P. H., and McCormick, A. V.: Determination of cloud condensation nuclei production from measured new particle formation events, Geophys. Res. Lett., 36, L06812, doi:10.1029/2004GL022092, 2009.

Kuang, C., Riipinen, I., Sihto, S.-L., Kulmala, M., McCormick, A. V., and McMurry, P. H.: An improved criterion for new particle formation in diverse atmospheric environments, Atmos. Chem. Phys., 10, 8469-8480, doi:10.5194/acp-10-8469-2010, 2010.

Kulmala, M., Vehkamaki, H., Petaja, T., Dal Maso, M., Lauri, A., Kerminen, V. M., Birmili, W., and McMurry, P. H.: Formation and growth rates of ultrafine atmospheric particles: a review of observations, J. Aerosol Sci., 35, 143-176, 2004.

Kupiainen, O., Ortega, I. K., Kurtén, T., and Vehkamäki, H.: Amine substitution into sulfuric acid - ammonia clusters, Atmos. Chem. Phys., 12, 3591-3599, doi:10.5194/acp-12-3591-2012, 2012.

Kurtén, T., Loukonen, V., Vehkamäki, H., and Kulmala, M.: Amines are likely to enhance neutral and ion-induced sulfuric acid-water nucleation in the atmosphere more effectively than ammonia, Atmos. Chem. Phys., 8, 4095-4103, doi:10.5194/acp-8-4095-2008, 2008.

Laaksonen, A., Hamed, A., Joutsensaari, J., Hiltunen, L., Cavalli, F., Junkermann, W., Asmi, A., Fuzzi, S., and Facchini, M. C.: Cloud condensation nucleus production from nucleation events at a highly polluted region, Geophys. Res. Lett., 32, L06812, doi:10.1029/2004GL022092, 2005.

Lane, T. E., Donahue, N. M., and Pandis, S. N.: Effect of $\mathrm{NO}_{\mathrm{x}}$ on secondary organic aerosol concentrations, Environ. Sci. Technol., 42, 6022-6027, 2008.

Lee, A., Goldstein, A. H., Keywood, M. D., Gao, S., Varutbangkul, V., Bahreini, R., Ng, N. L., Flagan, R. C., and Seinfeld, J. H.: Gas-phase products and secondary aerosol yields from the ozonolysis of ten different terpenes, J. Geophys. Res., 111, D17305, doi:10.1029/2006JD007050, 2006.

Lee, B. H., Pierce, J. R., Engelhart, G. J., and Pandis, S. N.: Volatility of secondary organic aerosol from the ozonolysis of monoterpenes, Atmos. Environ., 45, 2443-2452, 2011.

McGraw, R. and Saunders, J. H.: A Condensation Feedback Mechanism for Oscillatory Nucleation and Growth, Aerosol Sci. Technol., 3, 367-380, 1984.

McMurry, P. H., Fink, M., Sakurai, H., Stolzenburg, M. R., Mauldin, R. L., Smith, J., Eisele, F., Moore, K., Sjostedt, S., Tanner, D., Huey, L. G., Nowak, J. B., Edgerton, E., and Voisin, D.: A criterion for new particle formation in the sulfur-rich Atlanta atmosphere, J. Geophys. Res., 110, D22S02, doi:10.1029/2005JD005901, 2005.

Merikanto, J., Spracklen, D. V., Mann, G. W., Pickering, S. J., and Carslaw, K. S.: Impact of nucleation on global CCN, Atmos. Chem. Phys., 9, 8601-8616, doi:10.5194/acp-9-8601-2009, 2009.

Metzger, A., Verheggen, B., Dommen, J., Duplissy, J., Prevot, A. S. H., Weingartner, E., Riipinen, I., Kulmala, M., Spracklen, D. V., Carslaw, K. S., and Baltensperger, U.: Evidence for the role of organics in aerosol particle formation under atmospheric conditions, P. Natl. Acad. Sci. USA, 107, 6646-6651, 2010. 
Nadykto, A. B., Yu, F. Q., Jakovleva, M. V., Herb, J., and Xu, Y. S.: Amines in the Earth's Atmosphere: A density functional theory study of the thermochemistry of pre-nucleation clusters, Entropy, 13, 554-569, 2011.

Paasonen, P., Nieminen, T., Asmi, E., Manninen, H. E., Petäjä, T., Plass-Dülmer, C., Flentje, H., Birmili, W., Wiedensohler, A., Hõrrak, U., Metzger, A., Hamed, A., Laaksonen, A., Facchini, M. C., Kerminen, V.-M., and Kulmala, M.: On the roles of sulphuric acid and low-volatility organic vapours in the initial steps of atmospheric new particle formation, Atmos. Chem. Phys., 10, 11223-11242, doi:10.5194/acp-10-11223-2010, 2010.

Paulson, S. E., Chung, M., Sen, A. D., and Orzechowska, G.: Measurement of $\mathrm{OH}$ radical formation from the reaction of ozone with several biogenic alkenes, J. Geophys. Res., 103, 2553325539, 1998.

Perraud, V., Bruns, E. A., Ezell, M. J., Johnson, S. N., Yu, Y., Alexander, M. L., Zelenyuk, A., Imre, D., Chang, W. L., Dabdub, D., Pankow, J. F., and Finlayson-Pitts, B. J.: Nonequilibrium atmospheric secondary organic aerosol formation and growth, $\mathrm{P}$. Natl. Acad. Sci. USA, 109, 2836-2841, 2012.

Riipinen, I., Sihto, S.-L., Kulmala, M., Arnold, F., Dal Maso, M., Birmili, W., Saarnio, K., Teinilä, K., Kerminen, V.-M., Laaksonen, A., and Lehtinen, K. E. J.: Connections between atmospheric sulphuric acid and new particle formation during QUEST III-IV campaigns in Heidelberg and Hyytiälä, Atmos. Chem. Phys., 7, 1899-1914, doi:10.5194/acp-7-1899-2007, 2007.

Siese, M., Becker, K. H., Brockmann, K. J., Geiger, H., Hofzumahaus, A., Holland, F., Mihelcic, D., and Wirtz, K.: Direct measurement of $\mathrm{OH}$ radicals from ozonolysis of selected alkenes: A EUPHORE simulation chamber study, Environ. Sci. Technol., 35, 4660-4667, 2001.

Sihto, S.-L., Kulmala, M., Kerminen, V.-M., Dal Maso, M., Petäjä, T., Riipinen, I., Korhonen, H., Arnold, F., Janson, R., Boy, M., Laaksonen, A., and Lehtinen, K. E. J.: Atmospheric sulphuric acid and aerosol formation: implications from atmospheric measurements for nucleation and early growth mechanisms, Atmos. Chem. Phys., 6, 4079-4091, doi:10.5194/acp-6-4079-2006, 2006.

Smith, J. N., Barsanti, K. C., Friedli, H. R., Ehn, M., Kulmala, M., Collins, D. R., Scheckman, J. H., Williams, B. J., and McMurry, P. H.: Observations of aminium salts in atmospheric nanoparticles and possible climatic implications, P. Natl. Acad. Sci. USA, 107, 6634-6639, 2010.

Stolzenburg, M. R., McMurry, P. H., Sakurai, H., Smith, J. N., Mauldin, R. L., Eisele, F. L., and Clement, C. F.: Growth rates of freshly nucleated atmospheric particles in Atlanta, J. Geophys. Res., 110, D22S05, doi:10.1029/2005JD005935, 2005.

Szmigielski, R., Surratt, J. D., Gomez-Gonzalez, Y., Van der Veken, P., Kourtchev, I., Vermeylen, R., Blockhuys, F., Jaoui, M., Kleindienst, T. E., Lewandowski, M., Offenberg, J. H., Edney, E. O., Seinfeld, J. H., Maenhaut, W., and Claeys, M.: 3-methyl1,2,3-butanetricarboxylic acid: An atmospheric tracer for terpene secondary organic aerosol, Geophys. Res. Lett., 34, L24811, doi:10.1029/2007GL031338, 2007.

Tao, Y. and McMurry, P. H.: Vapor-pressure and surface freeenergies of C14-C18 monocarboxylic acids and C5-dicarboxylic and C6-dicarboxylic acids, Environ. Sci. Technol., 23, 1519$1523,1989$.
VanReken, T. M., Greenberg, J. P., Harley, P. C., Guenther, A. B., and Smith, J. N.: Direct measurement of particle formation and growth from the oxidation of biogenic emissions, Atmos. Chem. Phys., 6, 4403-4413, doi:10.5194/acp-6-4403-2006, 2006.

Veres, P., Roberts, J. M., Warneke, C., Welsh-Bon, D., Zahniser, M., Herndon, S., Fall, R., and de Gouw, J.: Development of negativeion proton-transfer chemical-ionization mass spectrometry (NIPT-CIMS) for the measurement of gas-phase organic acids in the atmosphere, Int. J. Mass Spectr., 274, 48-55, 2008.

Veres, P., Roberts, J. M., Burling, I. R., Warneke, C., de Gouw, J., and Yokelson, R. J.: Measurements of gas-phase inorganic and organic acids from biomass fires by negative-ion proton-transfer chemical-ionization mass spectrometry, J. Geophys. Res., 115, D23302, doi:10.1029/2010JD014033, 2010.

Viitanen, A. K., Saukko, E., Virtanen, A., Yli-Pirila, P., Smith, J. N., Joutsensaari, J., and Makela, J. M.: Ion mobility distributions during the initial stages of new particle formation by the ozonolysis of alpha-pinene, Environ. Sci. Technol., 44, 8917-8923, 2010.

Wagener, S., Langner, M., Hansen, U., Moriske, H. J., and Endlicher, W. R.: Spatial and seasonal variations of biogenic tracer compounds in ambient PM10 and PM1 samples in Berlin, Germany, Atmos. Environ., 47, 33-42, 2011.

Wang, L., Lal, V., Khalizov, A. F., and Zhang, R. Y.: Heterogeneous chemistry of alkylamines with sulfuric acid: Implications for atmospheric formation of alkylaminium sulfates, Environ. Sci. Technol., 44, 2461-2465, 2010a.

Wang, L., Khalizov, A.F., Zheng, J., Xu, W., Ma, Y., Lal, V., and Zhang, R.Y.: Atmospheric nanoparticles formed from heterogeneous reactions of organics, Nat. Geosci., 3, 238-242, doi:10.1038/NGEO778, 2010b.

Weber, R. J., Marti, J. J., McMurry, P. H., Eisele, F. L., Tanner, D. J., and Jefferson, A.: Measured atmospheric new particle formation rates: Implications for nucleation mechanisms, Chem. Eng. Commun., 151, 53-64, 1996.

Weber, R. J., Marti, J. J., McMurry, P. H., Eisele, F. L., Tanner, D. J., and Jefferson, A.: Measurements of new particle formation and ultrafine particle growth rates at a clean continental site, J. Geophys. Res., 102, 4375-4385, 1997.

Weber, R. J., Chen, G., Davis, D. D., Mauldin, R. L., Tanner, D. J., Eisele, F. L., Clarke, A. D., Thornton, D. C., and Bandy, A. R.: Measurements of enhanced $\mathrm{H}_{2} \mathrm{SO}_{4}$ and 3-4 nm particles near a frontal cloud during the First Aerosol Characterization Experiment (ACE 1), J. Geophys. Res., 106, 24107-24117, 2001.

Went, F. W.: Blue hazes in the atmosphere, Nature, 187, 641-643, 1960.

Winkler, P. M., Ortega, J., Karl, T., Cappellin, L., Friedli, H. R., Barsanti, K., McMurry, P. H., and Smith, J. N.: Identification of the biogenic compounds responsible for sizedependent nanoparticle growth, Geophys. Res. Lett., 39, L20815, doi:10.1029/2012GL053253, 2012.

Yasmeen, F., Vermeylen, R., Szmigielski, R., Iinuma, Y., Böge, O., Herrmann, H., Maenhaut, W., and Claeys, M.: Terpenylic acid and related compounds: precursors for dimers in secondary organic aerosol from the ozonolysis of $\alpha$ - and $\beta$-pinene, Atmos. Chem. Phys., 10, 9383-9392, doi:10.5194/acp-10-9383-2010, 2010.

Yli-Juuti, T., Barsanti, K., Hildebrandt Ruiz, L., Kieloaho, A.-J., Makkonen, U., Petäjä, T., Ruuskanen, T., Kulmala, M., and Riipinen, I.: Model for acid-base chemistry in nanoparticle growth 
(MABNAG), Atmos. Chem. Phys. Discuss., 13, 7175-7222, doi:10.5194/acpd-13-7175-2013, 2013.

Yu, F. and Luo, G.: Simulation of particle size distribution with a global aerosol model: contribution of nucleation to aerosol and CCN number concentrations, Atmos. Chem. Phys., 9, 76917710, doi:10.5194/acp-9-7691-2009, 2009.

Yu, H., McGraw, R., and Lee, S. H.: Effects of amines on formation of sub-3 nm particles and their subsequent growth, Geophys. Res. Lett., 39, L02807, doi:10.1029/2011GL050099, 2012.

Yu, J. Z., Cocker, D. R., Griffin, R. J., Flagan, R. C., and Seinfeld, J. H.: Gas-phase ozone oxidation of monoterpenes: Gaseous and particulate products, J. Atmos. Chem., 34, 207-258, 1999.

Zhang, Q., Jimenez, J. L., Canagaratna, M. R., Allan, J. D., Coe, H., Ulbrich, I., Alfarra, M. R., Takami, A., Middlebrook, A. M., Sun, Y. L., Dzepina, K., Dunlea, E., Docherty, K., DeCarlo, P. F., Salcedo, D., Onasch, T., Jayne, J. T., Miyoshi, T., Shimono, A., Hatakeyama, S., Takegawa, N., Kondo, Y., Schneider, J., Drewnick, F., Borrmann, S., Weimer, S., Demerjian, K., Williams, P., Bower, K., Bahreini, R., Cottrell, L., Griffin, R. J., Rautiainen, J., Sun, J. Y., Zhang, Y. M., and Worsnop, D. R.: Ubiquity and dominance of oxygenated species in organic aerosols in anthropogenically-influenced Northern Hemisphere midlatitudes, Geophys. Res. Lett., 34, L13801, doi:10.1029/2007GL029979, 2007.

Zhang, R. Y., Suh, I., Zhao, J., Zhang, D., Fortner, E. C., Tie, X. X., Molina, L. T., and Molina, M. J.: Atmospheric new particle formation enhanced by organic acids, Science, 304, 1487-1490, 2004.

Zhang, R. Y., Wang, L., Khalizov, A. F., Zhao, J., Zheng, J., McGraw, R. L., and Molina, L. T.: Formation of nanoparticles of blue haze enhanced by anthropogenic pollution, P. Natl. Acad. Sci. USA, 106, 17650-17654, 2009.
Zhang, R. Y., Khalizov, A., Wang, L., Hu, M., and Xu, W.: Nucleation and growth of nanoparticles in the atmosphere, Chem. Rev., 112, 1957-2011, 2012.

Zhao, J., Levitt, N. P., and Zhang, R.: Heterogeneous chemistry of octanal and 2, 4-hexadienal with sulfuric acid, Geophys. Res. Lett., 32, L09802, doi:10.1029/2004GL022200, 2005.

Zhao, J., Levitt, N. P., Zhang, R., and Chen, J.: Heterogeneous reactions of methylglyoxal in acidic media: implication for secondary organic aerosol formation, Environ. Sci. Technol., 40, 7682-7687, 2006.

Zhao, J., Khalizov, A., Zhang, R. Y., and McGraw, R.: HydrogenBonding Interaction in Molecular Complexes and Clusters of Aerosol Nucleation Precursors, J. Phys. Chem. A, 113, 80-689, 2009.

Zhao, J., Eisele, F. L., Titcombe, M., Kuang, C. G., and McMurry, P. H.: Chemical ionization mass spectrometric measurements of atmospheric neutral clusters using the cluster-CIMS, J. Geophys. Res., 115, D08205, doi:10.1029/2009JD012606, 2010.

Zhao, J., Smith, J. N., Eisele, F. L., Chen, M., Kuang, C., and McMurry, P. H.: Observation of neutral sulfuric acid-amine containing clusters in laboratory and ambient measurements, Atmos. Chem. Phys., 11, 10823-10836, doi:10.5194/acp-1110823-2011, 2011.

Zollner, J. H., Glasoe, W. A., Panta, B., Carlson, K. K., McMurry, P. H., and Hanson, D. R.: Sulfuric acid nucleation: power dependencies, variation with relative humidity, and effect of bases, Atmos. Chem. Phys., 12, 4399-4411, doi:10.5194/acp-12-43992012, 2012. 